\title{
ダム貯水池の内部静振と定常的往復流の メカニズムに関する研究 \\ A STUDY ON INTERNAL SEICHE AND STEADY OSCILLATING CURRENT IN A RESERVOIR
}

\author{
横山勝英 ${ }^{1} \cdot$ 新谷哲也 ${ }^{2}$ \\ Katsuhide YOKOYAMA, Tetsuya SHINTANI
}

$\begin{array}{llll}{ }^{1} \text { 正会員 } & \text { 博 }(工) & \text { 首都大学東京准教授 } & \text { 都市環境学部都市環境学科都市基盤環境コース ( 192-0397 八王子市南大沢 1-1) } \\ { }^{2} \text { 正会員 } & \text { 修 }(工) & \text { 首都大学東京助手 } & \text { 都市環境学部都市環境学科都市基盤環境コース (广 192-0397 八王子市南大沢 1-1) }\end{array}$

\begin{abstract}
A field measurement of an internal seiche induced current was undertaken in the Shichigasyuku reservoir. The vertical temperature profiles were monitored at seven stations; further, the current profile was obtained using bottom-mounted ADCP in the period between May to November, 2004. The period of thermocline oscillations matched the theoretical period of the internal seiche. The reciprocating motion of the water current was explained by the righting movement of the inclined water body. The reciprocating current was moved to upper layer. The 3-D numerical simulation explained that the wave motion occur when the lower water runup the sloping bottom that becomes narrow in upstream. The stationary reciprocating current reached $0.2 \mathrm{~m} / \mathrm{s}$ during spring and $0.05 \mathrm{~m} / \mathrm{s}$ during summer, and the cumulative transport distance of water particles over one week reached $6000 \mathrm{~m}$ during spring and $1000 \mathrm{~m}$ during summer. It is considered that the seiche-induced stationary current influences the circulation of the reservoir water.
\end{abstract}

Key Words: Field measurement, Internal seiche, sloping bottom

\section{1.はじめに}

大都市圏の周辺に建設された大型ダム貯水池は水道 水源としての役割を負うことが多いが, 近年は安全で 美味しい水道水が求められる傾向が強く，貯水池の水 質を良好に保つことが重要視されている.貯水池では 水温密度構造や流れによって溶存酸素や栄養塩, 懸濁 土砂の動きが規定されるため，水質を制御するために は流入水質の改善だけではなく, 貯水池内の密度構造 や流動を制御する必要がある。

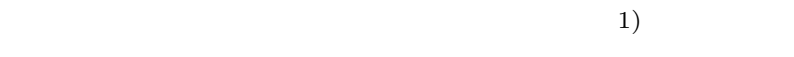
貫入流動 ${ }^{23)}$ などがあり, 人工的な強制流動としては 曝気循環 ${ }^{4)}$ や選択取水 ${ }^{5)}$, 分画フェンスによる流入水 の深層誘導 ${ }^{6)}$ などが挙げられ, 光れぞれ室内実験や現 地観測に基づく詳細な研究が実施されている.

一方, 琵琶湖 ${ }^{7)}$ や猪苗代湖 ${ }^{8)}$ などの大規模湖沼では 内部静振とコリオリカによる循環流の存在が明らかに されているが, 日本のダム貯水池は規模が小さいため
に定常的な流れの存在についてはほとんど着目されて いない，内部静振等の傾圧運動に伴う流動は吹送流に 比べて微少であるが，長期間継続するために貯水池内 の濁質・栄養塩の水平方向輸送に深く関わっている . 光 こで本研究では, ダム貯水池において水温分布と流動 に関する現地観測を行い，強風作用後に発生する内部 静振を駆動力とした定常的な流れの存在を明らかにす るとともに光の流動メカニズムを検討し，物質循環に 影響を及ぼすような有意な流れであるかどうかについ て考察した。

\section{2. 観測方法}

研究対象地は宮城県南部の七ヶ宿公貯水池である . 七ヶ宿多ムは 1989 年に湛水を開始した多目的公ムであ り，仙台市及び周辺地域への重要な水道水源ともなって いる. 総貯水容量は約 1 億 $\mathrm{m}^{3}$, 最大水深は $55 \mathrm{~m}$, 湛水 面積は $4.1 \mathrm{~km}^{2}$ であり，常時表層放流が行われている. 
流域人口は約 2,000 人と少なく下水道も整備されてい ることから流入水の栄養塩濃度は低く, 盯水池は中栄 養状態で維持されている.しかし, 1995 年頃から淡水 赤潮の発生が見られるようになり，水質管理上の課題 となっている .

観測項目は水温鉛直分布と流速鉛直分布であり，図-1 に示す地点に測定機器を設置した . 貯水池の水面形状は 直線的で比較的単純であるが，湖盆は図-2に示すよう に旧河道の澪筋と旧河岸段丘の浅瀬から構成された複 断面形状をしている. 光のため, 地形的な特徵を考慮し てサーミスターチェーンを澪筋に 4 点, 浅瀬に 3 点設置 し，超音波流速計を湖心部に設置した . 水温計は Onset 製 Tidbit (精度 0.2 度) を使用し，これらをロープに $2.5 \sim 5 \mathrm{~m}$ 間隔で取り付けたサーミスターチェーンを 7 本 作成した . 水温計の使用数は 69 個であり，10 分間隔で 計測した．超音波流速計は RDI 製 WH-ADCP $600 \mathrm{kHz}$ を用い, 層厚 $0.4 \mathrm{~m}$, 精度 $0.8 \mathrm{~mm} / \mathrm{s}$ に設定して 20 分間 隔で計測した．超音波流速計は湖底から上方を計測す

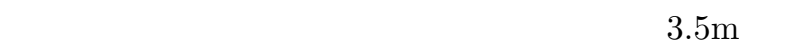
感帯となった．観測期間は 2004 年 5 月 15 日から 11 月 25 日までの約 6 ケ月間であるが , 計測上のトラブルに より全てのデータセットが揃って得られたのは 3.5 月 分であった .

\section{3. 水温変動と 静振}

図-3 に春期（5月）の風速と水温分布状況を，図-4 に夏期 (8月) の状況を示す.七ヶ宿名貯水池では湖 面の長軸方向に卓越風が吹くため，長軸に沿った方向

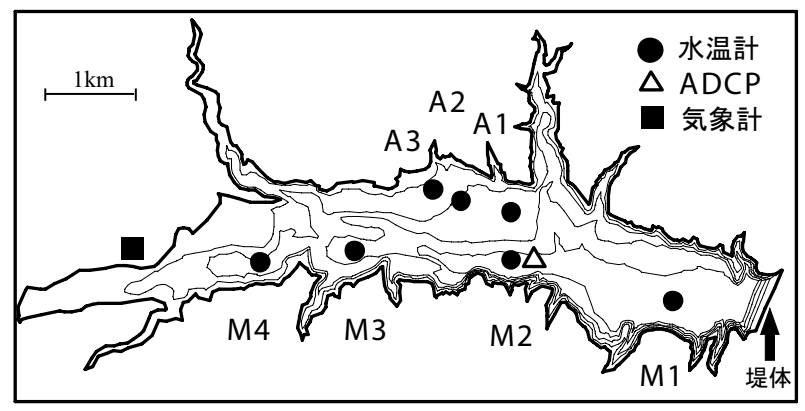

図-1 測定機器設置地点

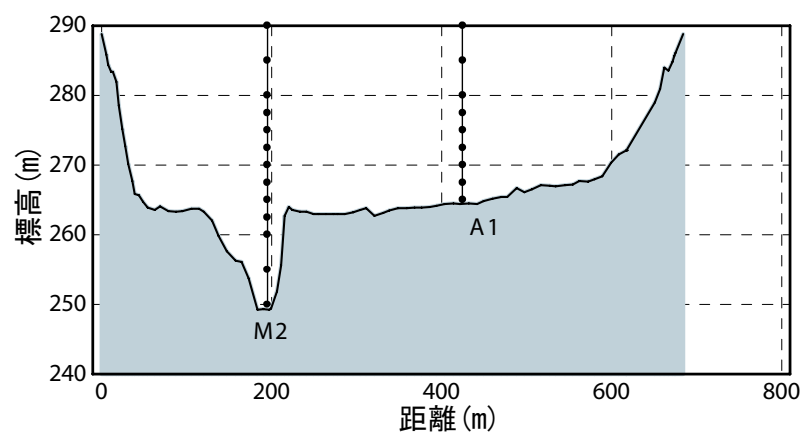

図-2 複断面形状（湖心付近の横断図）
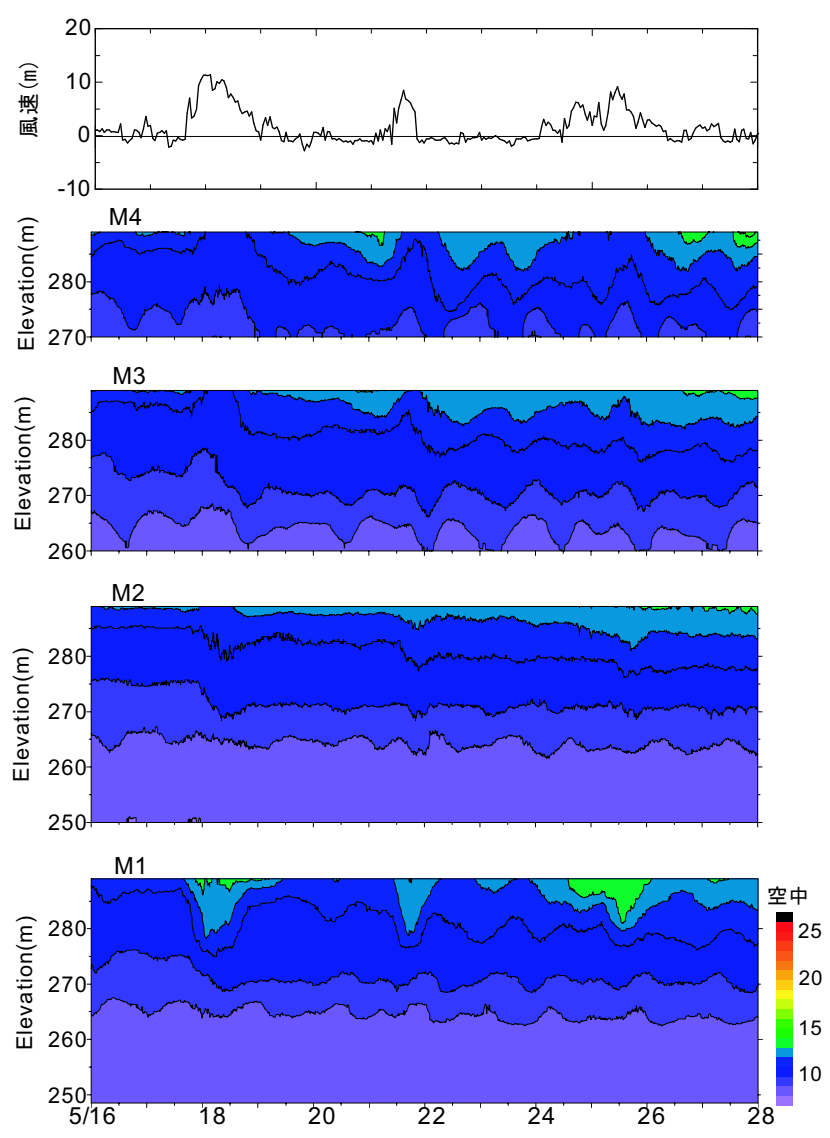

図-3 春期 (5月) の風速と水温分布
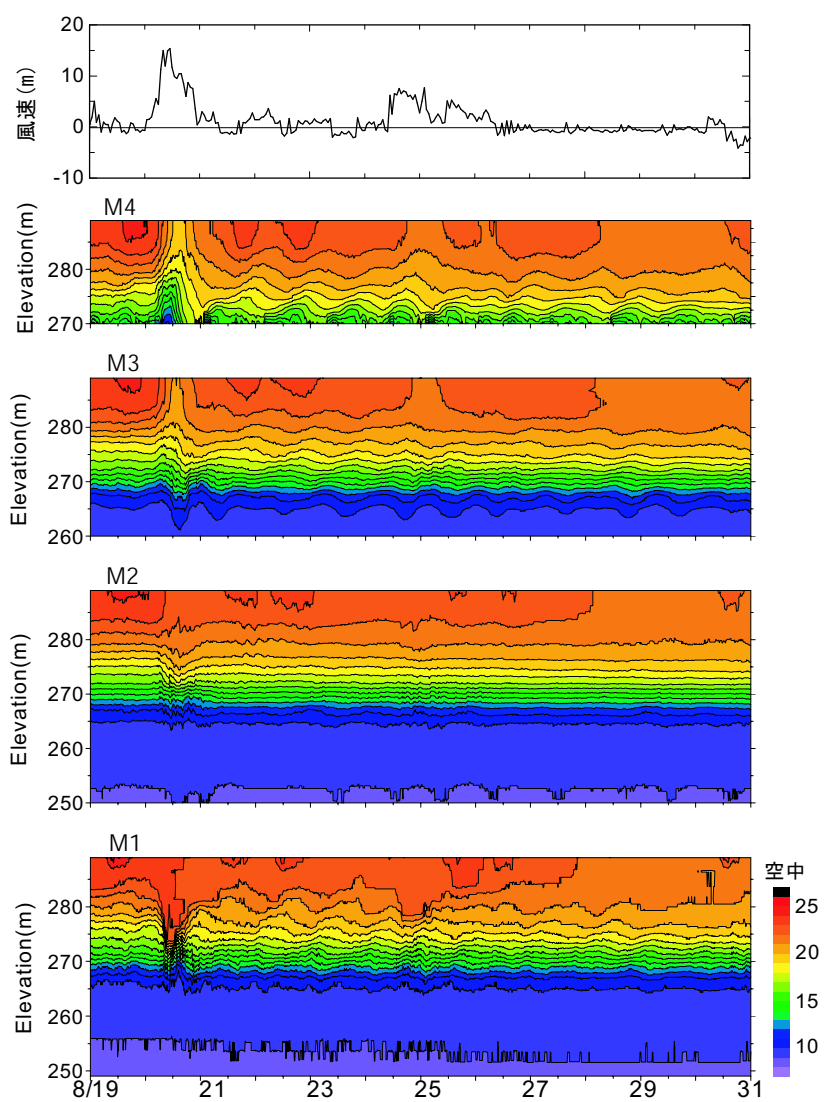

図-4 夏期 (8 月) の風速と水温分布 
(a) 09:30

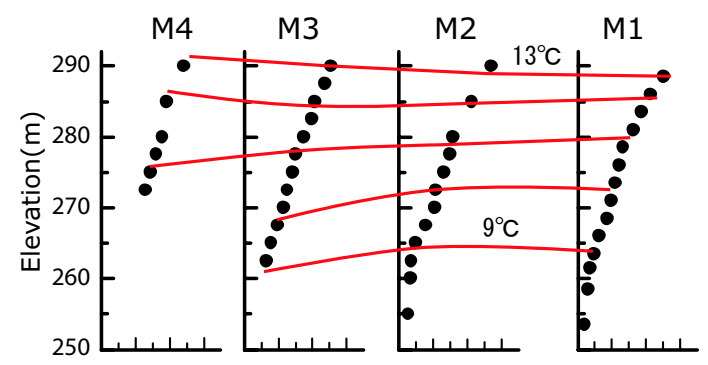

(b) $19: 30$

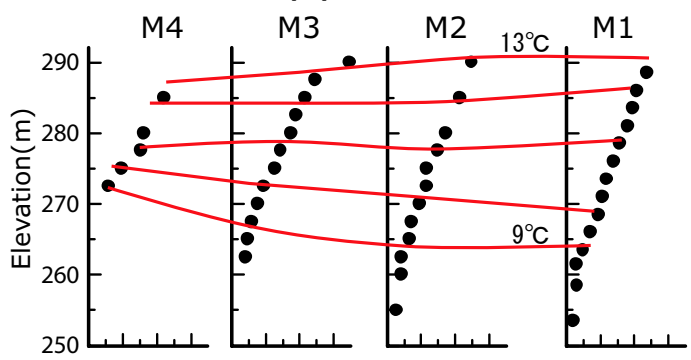

図-5 水温縦断分布図

で風の強さを示し, 上流から堤体に向かって順方向と定 義する. また, 図中の空中部分 (黑) は, 水位変動を示 すために描いてある.春期 (図-3) は湖底が 8 度, 表層 が 13 度であり弱い連続成層となっている. 5 月 18 日, 21 日,25 日に光れ光れ風速 $8 \mathrm{~m}$ 以上の順風が吹いており， 弚れによって水温が大きく変動している.5月 17 日か ら 19 日にかけての強風時には, 貯水池上流部の M 3 と M4 において等温線が上昇し，中・下層水が表層に持ち 上がるような挙動をしており，乥の後等温線に周期的 な振動が発生している . 貯水池中央部の M2 では成層 構造の変動は見られず，下流の M1 では上流とは逆に 温水が表層に現れる。

夏期 (図-4) は表層が 25 度に達して成層か溞化され ているため, 風に起因する成層構造の振動は春期ほど には顕著ではない，しかし, 風速 $15 \mathrm{~m}$ を越える風が吹 いた 8 月 20 日には上流の M4 において水深 $13 \mathrm{~m}$ (標高 $275 \mathrm{~m})$ に存在した水温 20 度の水が表面に持ち上がり， 下流の M1 では表層水が水深 $13 \mathrm{~m}$ まで潜り込む現象が 見られ，風に起因するダイナミックな運動が発生して いることが伺える。

水温成層の空間的な振動の一例として，図-5に 5 月 27 日の水温縦断分布図を示す.9:30 には上層では等值 面が上流側（M4）で $2 \mathrm{~m}$ ほど高く，9 度〜10 度の下層 水が上流部 (M3) で潜り込んでいる.一方，12 時間後 の 19:30 には逆に上層の等値面が上流側で $3 \mathrm{~m}$ ほど下が り，下層水が上流側で湧き上がっており，等值面の上昇 高さは $12 \mathrm{~m}$ にも及んでいる

水温躍層付近に存在する等温線の上下変動をスペク トル解析すると図-6 が得られた . 等温線の变動周期は 5 月には 28 時間と 18.7 時間が, 8 月は 24 時間と 14 時 (a) 5 月, $10^{\circ} \mathrm{C}$

(b) 8 月, $15^{\circ} \mathrm{C}$
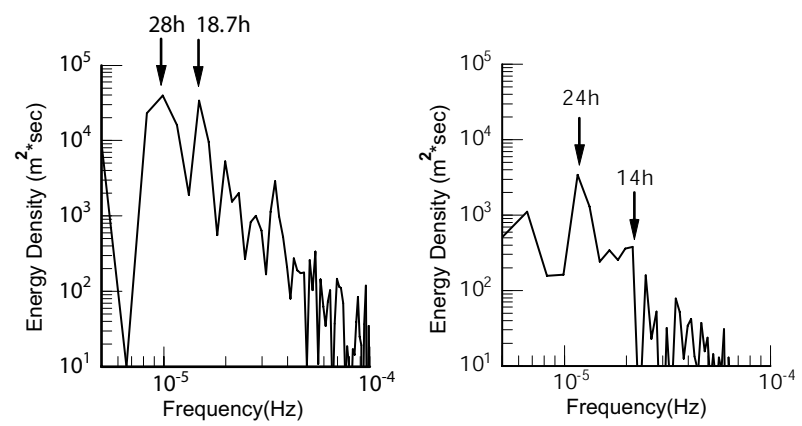

図-6 等温線のスペクトル解析結果

表-1 静振周期の理論計算

基本振動数 (Brunt-Vaisala frequency) $\mathrm{N}$

$$
N^{2}=-\frac{g}{\rho} \frac{\partial \rho}{\partial z}
$$

角振動数 $\omega$ (水平方向波数 $k$, 鉛直方向波数 $m$ )

$$
\omega=N \sqrt{\frac{k^{2}}{k^{2}+m^{2}}}
$$

水平 - 鉛直方向波数 $k, m$ (水平 - 鉛直方向波長 $L_{x}, L_{z}$ )

$$
k=\frac{2 \pi}{L_{x}}, \quad m=\frac{2 \pi}{L_{z}}
$$

周期 $T$

$$
T=\frac{2 \pi}{\omega}
$$

表-2 成層の振動モードと周期

\begin{tabular}{|c||c|c|c|c|}
\hline \multicolumn{1}{|c||}{} & \multicolumn{2}{c|}{5} & \multicolumn{2}{c|}{8} \\
\hline \hline 水平モード & 1 次 & 1 次 & 1 次 & 1 次 \\
\hline $\mathrm{Lx}(\mathrm{m})$ & 3400 & 3400 & 3400 & 3400 \\
\hline $\mathrm{k}$ & 0.0009 & 0.0009 & 0.0009 & 0.0009 \\
\hline \hline 鉛直モード & 1 次 & 2 次 & 2 次 & 3 次 \\
\hline $\mathrm{Lz}(\mathrm{m})$ & 30 & 30 & 30 & 30 \\
\hline $\mathrm{m}$ & 0.1047 & 0.2093 & 0.2093 & 0.314 \\
\hline$\omega$ & 0.0001 & 0.0001 & 0.0001 & 0.0001 \\
\hline $\mathrm{T}($ hour $)$ & 18.2 & 36.4 & 15.7 & 23.6 \\
\hline
\end{tabular}

間が卓越していた .一方，連続成層場における内部静振 の理論的な周期は表-1のように表される .これらの式 に各季節の成層状態に関する值を代入すると表-2 が得 られた .この表において，基本振動数を計算する際に は，5月，8 月共に表層と底層における水温を直線的に 結んだ温度分布 (連続成層) を仮定して計算を行った。

成層の振動周期は長軸方向の内部静振で概ね説明さ れ，鉛直方向に見ると 5 月は 1 次モード (2 層状態)， 8 月は 2 次モード (3 層状態) と 3 次モード (4 層状態) の 2 つで運動していると言える.なお， 5 月のスペクト ルでは 28 時間周期が卓越しているが，これは内部静振 では説明が付かない，乥こで，長軸方向の風速につい てスペクトル解析を行うと，12 時間周期が卓越してい た 、これは昼間に風力溞く, 朝夕は弱くなる状態を表し ており，風によって誘起される吹送流の周期と内部静 振の理論周期が一致しないために生じた現象ではない かと推測される. 8 月は風の周期と静振の周期が一致し ているため, 日周変動成分が最も強く表れている．ま 
た, 短軸方向には静振が発達していないことが分かっ た .これは山間の貯水池では谷筋方向に卓越風が吹く ためである .

\section{4.静振と流動}

図-7 に湖心部 (M2) における 5 月の流速分布図を， 図-8に 8 月の流速分布を示す. 5 月 18 日と 21 日，8 月 20 日には強い順風が吹き, 水面下 $5 \mathrm{~m}$ までは吹送流 が発達し, 弚れよりも深い場所で補償流として強い逆 流が生じている.さらに光の後, 周期的な往復流が発 生している. 5 月は $100 \mathrm{~mm} / \mathrm{s}$ 程度の往復流が, 8 月は $50 \mathrm{~mm} / \mathrm{s}$ 程度の流れが見られる .また , 標高 $267 \mathrm{~m}$ から 湖底にかけては単純な往復流であるが, 弚れよりも上 部の連続成層場では, 正負の流速 (赤色と青色) の分 布が，下層部分の樣に鉛直方向に一樣ではなく，時間 と共に上方に伝搬するような波動性の現象が見られる .

図-9に残差流と水温の鉛直分布を示す . 残差流の平 均期間は静振周期の 2 倍にとり，5 月は 36 時間 , 8 月 は 48 時間とした . 5 月は水温は連続的であるが流速場 は 2 ないし 3 成層のようになっており, 上層も下層も 堤体側に向かう残差流か涀れている.8月の流速場は 4 成層をなしており，残差流は弱いながらも堤体側に向 かっている.

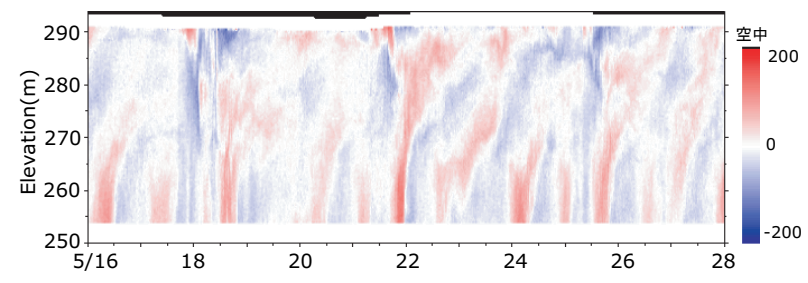

図-7 5 月の鉛直流速分布 $(\mathrm{mm} / \mathrm{s})$

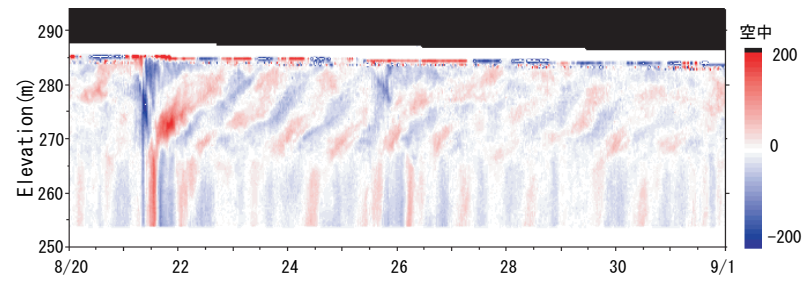

図-8 8 月の鉛直流速分布 $(\mathrm{mm} / \mathrm{s})$
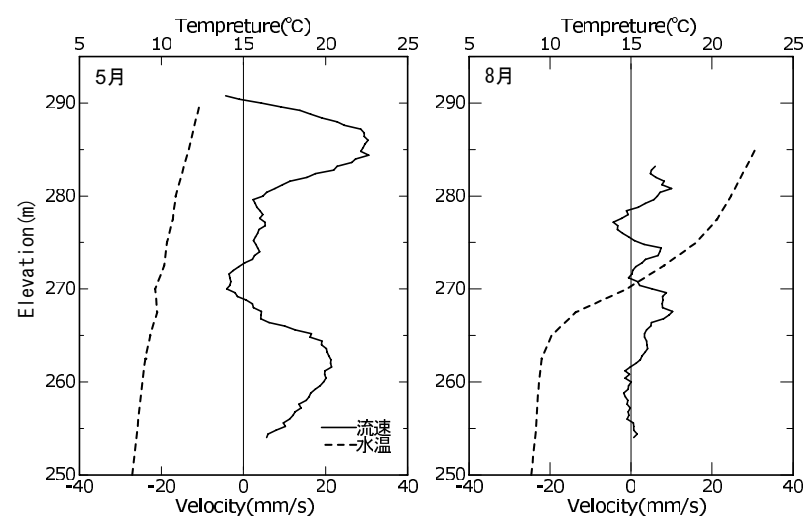

図-9 残差流と水温の鉛直分布
まず，底層の流速について検討を進める .上流（M3） と下流 (M1) の水温躍層の傾きと湖心部の流速の関係 を図-10 に示す . 水温躍層の傾きは躍層下端に位置する 水温 10 度の標高差で表し, 上流が持ち上がった場合を プラスで表現している . 両者の運動の周期性は非常に 良く似ており，流速変動をスペクトル解析すると図-6 で示した成層振動の周期と完全に一致していた .

躍層の傾きと流速の相互相関を調べたところ，5月は 4.67 時間のラグで相関が最大となり，8 月は 6.67 時間 であつた .これは内部静振のモードを 5 月は 1 次 , 8 月 は 3 次とした場合の振動周期や流速周期の約 4 分の 1 に相当する．したがって，躍層が最も傾いたときに流 れが停止し，水平な時に流速が最大になっており，底 層水の運動が内部静振によって引き起こされているこ とが示された .

また，躍層の振幅について調べたところ(図-12)，上 流では下流の 3.6 倍大きくなっていた .この原因は , 貯 水地形状にあると考えられる．すなわち，七ヶ宿貯水 池は多么堤体から上流に向かって断面積が減少してお り，上流では約 4 分の 1 に狭まっている . 上流側と下 流側に移動する下層水のフラックスが同等であると考 えると，断面積と振幅は逆比例の関係にあり，上流ほ ど振幅が大きくなるものと考えられる . 上流側におい て断面積が減少し，さらに緩斜面となっていることに より，静振の運動は左右非対称になる．

次に, 躍層よりも上部における流速変動について考 察する . 矩形水槽における内部静振は節の水深が固定 されるため, 流速変動は 8 月 (図-8) の下層のような 単純な往復流しか現れないはずであるが，実際には表 面に向かって上ってゆくような流速場が発生している． これは水塊が上昇しているのではなく，波の腹と節が 徐々に上方に伝搬している樣子を表している . 乥こで， このような波動の伝搬が湖底形状の影響を受けた静振 の非対称性によって生じていると考え，次に数值実験 を行う.
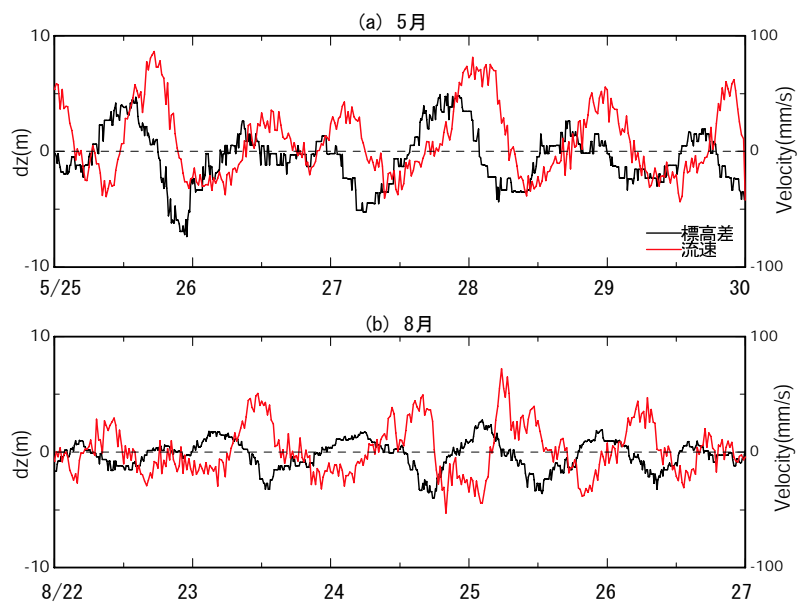

図-10 水温成層の傾きと湖心部流速 
(a) 5 月

(b) 8 月
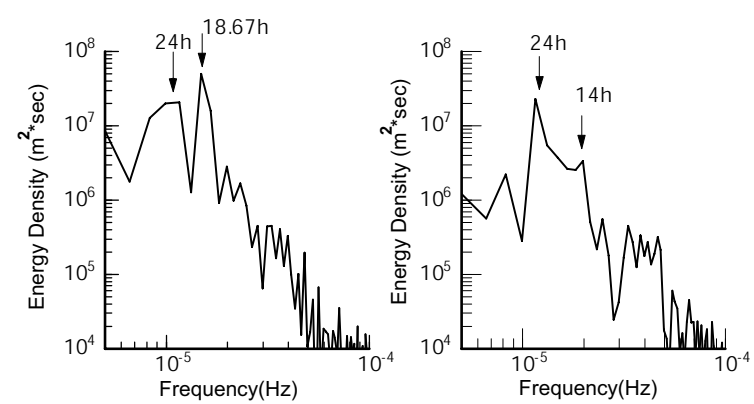

図-11 流速変動のスペクトル
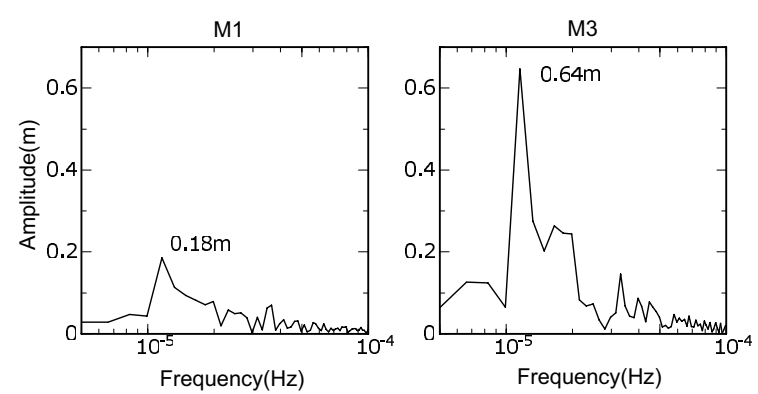

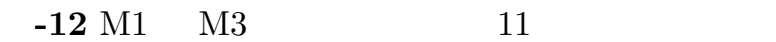

\section{5. 数值実験}

数值モデルは新谷ら ${ }^{9)}$ が密度成層場の水槽実験用に 開発したものを用いる.基礎方程式は連続式，3 次元 Navier-Stokes 式, 密度の輸送方程式であり，デカルト 座標スタッガード格子上で離散化した . 数值解法には Fractional-Step 法を用い，支配方程式の移流項の差分 には有理関数 CIP 法を用いている．また，圧力補正値に 関する Poisson 方程式の解法には残差切除法を用いた .

このモデルを用いて , 通常の矩形水路と貯水地形状を 模擬した斜面水路において内部静振の運動の違いを検証 する . 矩形水域の大きさは長さ $120 \mathrm{~cm}(x)$, 幅 $30 \mathrm{~cm}(y)$, 深さ $30 \mathrm{~cm}(z)$ とした．また，斜面水路では片側に上流 断面積が勾配 $1 / 3$ で線形的に縮小してゆく $\mathrm{V}$ 字谷を設 けた .

成層構造は, 深さ $15 \mathrm{~cm}$ 以下が一定密度 $\left(1004 \mathrm{~kg} / \mathrm{m}^{3}\right)$, 上層は水面に向かって密度が線形的に減少する連続成 層とし, 成層内の最大密度差は $4.0 \mathrm{~kg} / \mathrm{m}^{3}$ とした. 水域 内に内部静振を引き起こすために成層を静止状態で 15 度ほど水平から傾かせて計算を開始した .なお, 躍層の 変動モードを確認することを目的としているため, 乱 流モデルは用いていない .

湖心部分 $(x=60 \mathrm{~cm}, y=15 \mathrm{~cm})$ における流速の計算結 果を図-13 に示す. 矩形水路 (a) では水深 $15 \mathrm{~cm}$ の躍層 を境にした単純な往復流しか発生しておらず, 理論的 な内部静振の運動を表現出来ている.一方，斜面水路 (b) では現地観測で見られたような上方に流速が伝搬し てゆく樣子が捉えられている .

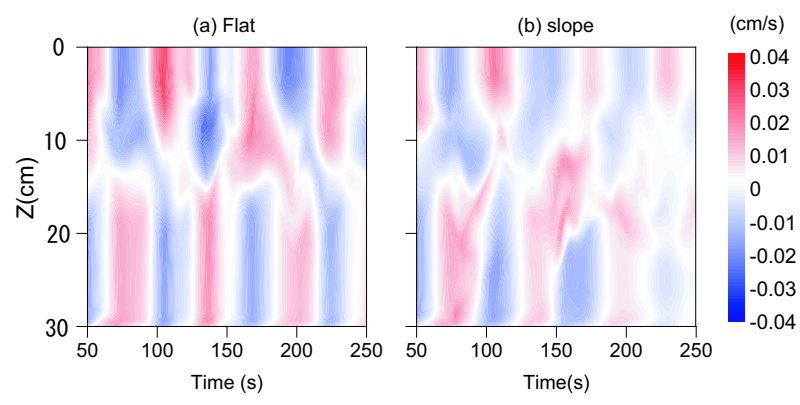

図-13 湖心部の鉛直流速分布 (数値実験結果)

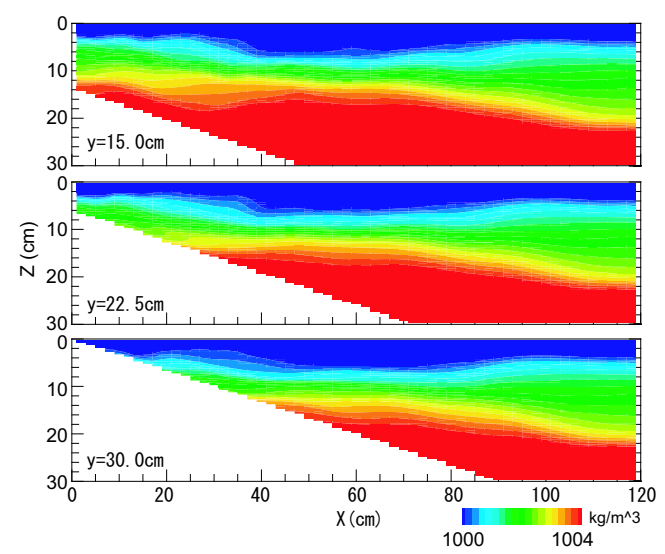

図-14 3 次元密度変動状況 (数值実験結果)

図-14 は斜面水路における密度成層場の変動状況を $\mathrm{y}=15 \mathrm{~cm}$ (中央) $, \mathrm{y}=22.5 \mathrm{~cm}, \mathrm{y}=30 \mathrm{~cm}$ (側面) の鉛直 断面で示している.中央断面における密度分布から，上 流側 $(\mathrm{x}=0 \mathrm{~cm})$ の $\mathrm{V}$ 字谷斜面において下層水が湧昇し， 躍層上部の成層構造に影響を及ぼしている樣子が見て 取れる．これらの結果は，現地観測で得られた特徵的 な流動現象の原因が斜面の存在で生じた可能性を示し ており, 湖底に存在する斜面地形と内部波 (内部静振) の干渉及び斜面の存在による断面積の縮小が湖内の流 動に顕著な影響を及ぼしていることが明らかとなった .

\section{6. 水塊の移動量}

貯水池の流れが物質輸送に及ぼす影響を考察するた めに, 湖心部 (M2) の水塊の移動距離を調べた . 図15 は 5 月と 8 月の上層 (EL.280) 中層 (EL.270) 下層 (EL.260) の累積移動距離を示している．これより，5 月は上層では正味の移動量がわずかにプラスであるが， これは期間の取り方によって異なるため，有意な移動 があるとは言い切れない .しかし , 中層と下層では明ら かにダム堤体に向かう流れが卓越しており，中層では 1 週間で $1,500 \mathrm{~m}$ ，下層では $6,000 \mathrm{~m}$ の移動が見られた . 湖心部は標高 $267 \mathrm{~m}$ 以深が狭窄部となっているため，下 層での移動か湿著になったものと考えられる .8月も同 樣の傾向であるが , 中下層では 1 日に 500〜 800m ずつ 振動して，一週間で堤体方向に 1,000 2,000m の移動 
(a) 5 月

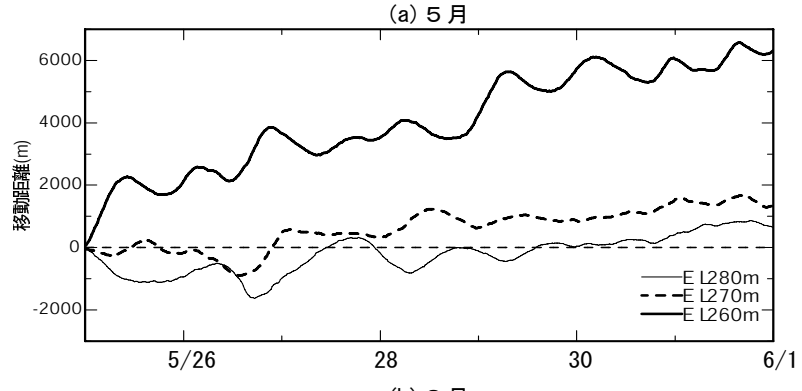

(b) 8 月

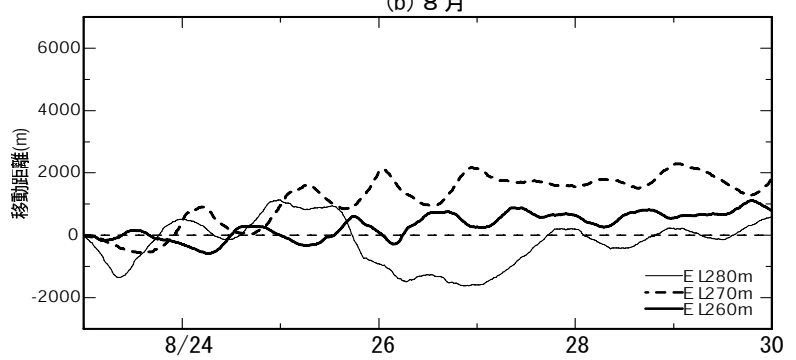

図-15 5月と 8月の累積移動距離

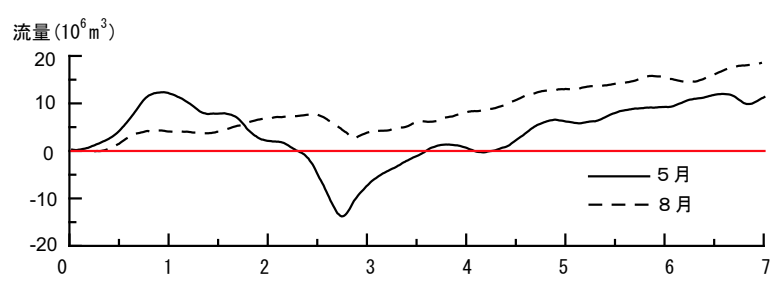

図-16 断面通算流量 (a) 5月，(b) 8月

があるものと推定された . 湖心から堤体までの距離は 約 $1.5 \mathrm{~km}$ であるから，活発な輸送が生じていると言え る . 次に , 湖心部の流速鉛直分布か貯水池の横断方向に も均一に分布していると仮定して断面通過流量を算定 したところ，図-16 が得られた . 一週間で 1000〜1500 万 $\mathrm{m}^{3}$ の順流が生じている結果となった . しかし，河 川水の流入量と貯水池放流量は, 5 月が 554 万 $\mathrm{m}^{3}, 698$ 万 $\mathrm{m}^{3}, 8$ 月が 278 万 $\mathrm{m}^{3}, 367$ 万 $\mathrm{m}^{3}$ であり，推定された 断面通過流量とかけ離れている.したがって, 横断方 向に流速が均一とした仮定が間違っており，実際には 流速の横断分布があると見るべきである．断面通過流 量の推定值が実際の值の 2 倍以上であることや , 図-16 の累積移動量か貯水池の湛水延長 $(4000 \mathrm{~m})$ の半分程 度にも及ミ゙ことから，湖心部の流速が全体に及んでい るのではなく，水平循環流が生じている可能性が高い． この水平循環流発生は, 本貯水池の湖盆形状が長軸方 向に澪筋 (深部) と河岸段丘 (浅瀬) を持つ複断面を 形成していることが一要因であると予想される .

\section{7. まとめ}

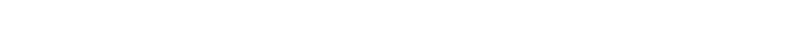
速の現地観測を行い，内部静振によって日常的に生じ る流動現象が貯水池内の物質循環に寄与する可能性に ついて検討した . まず, 多点水温観測の結果から，貯
水池内には内部静振が長期にわたって継続しているこ とが確認できた．また，等温線の変動解析結果から成 層変位の非対称性が明らかとなり，成層運動が斜面か ら構成される湖底地形の影響を強く受けることが明ら かとなった . ADCP による流動観測の結果からは，最 大約 $200 \mathrm{~mm} / \mathrm{s}$ の水平流速が湖心において生じること が明らかとなった . また，流速の鉛直分布の時系列か ら，上方へ内部波運動が伝播していると予想される現 象を見つけることができた .この結果の原因を究明す るために, 湖底形状を模擬した水路の 3 次元数值解析 を行った . 兴の結果 , 斜面形状の湖底地形が湖内の流動 を大きく変化させる効果を持つことが明らかとなった． 最後に, $\mathrm{ADCP}$ の結果から水塊の累積移動距離と断面 通算流量を算出した . 累積移動距離からは , 澪筋に沿っ て提体に向かう活発な水平輸送か確認され，内部静振 による定常的な流れが物質輸送に影響を及ぼす可能性 があることがわかった . また，断面通算流量の推定值 は，実際の貯水池の流入出量と一致せず，貯水池内に 水平循環流が存在することを示唆する結果となった .

謝辞 本研究を実施するにあたり東京工業大学大学院石川忠 晴教授には多くの助言及び協力をいただいた . 現地観測の際

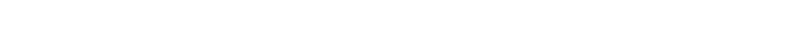
大なるご助力をいただいた . 首都大学東京都市基盤環境コー ス水工学研究室の学生諸氏にはデータ整理及び作図を協力し ていただいた .ここに記して謝意を表する．

\section{参考文献}

1) 矢島啓, 道上正則, 檜谷治, 宇田康弘:浅い汽水湖における密 度成層破壊の数值解析, 水工学論文集, 第 44 巻, pp.993-998, 2000

2) 福岡捷二, 福島祐介, 村田和夫, 荒井健 : 成層化した二次 元貯水池に流入する密度流の実験的研究, 土木学会論文集, No.293, pp.65-77, 1980

3) 梅田信 , 横山勝英 , 石川忠晴 , 銭新 , 高橋迪夫 : 七ヶ宿貯 水池における濁質の流入・流動・堆積過程に関する観測と数 值シミュレーション，土木学会論文集，No.656, pp.255-268, 2000.8

4) 梅田信, 宮崎貴紅子, 富岡誠司：曝気式循環施設により 生じる貯水池内流動の現地観測，土木学会論文集，No.775, pp.55-68, 2004.11

5) 有田正光 : 選択取水効率向上の一手法に関する研究, 水工 学論文集 , 第 41 巻, pp289-294, 1997

6) 秋山壽一郎, 西恭太 , 浦勝 : 潜入密度流の流動特性とフェン ス工による流動制御，水工学論文集，第 47 巻, pp.1177-1182, 2003

7)M.Kumagai,Y.Asada, and S.Nakano: Gyres Measured by ADCP in Lake Biwa, Coastal and Estuarine Studies Volume 54, pp.199-208, 1998

8) 戶塚康則, 田中仁, 藤田豊, 山路弘人, 愛川薰, 多久和学, 沢本正樹: 猪苗代湖における内部静振観測, 水工学論文集, 第 45 巻, pp.1177-1182, 2001

9) 新谷哲也, 梅山元彦 : 風応力による三成層水域の応答に関 する数值解析, 水工学論文集, 第 46 巻, pp.1007-1012,2002

(2005.9.30 受付) 